\title{
The Impact of the European Convention \\ on Human Rights (ECHR) \\ on Preventive Police Detention \\ as Governed by German Law
}

\author{
Clara Herz* \\ University of Passau \\ Germany
}

Received 11.03.2017, received in revised form 21.04.2017, accepted 05.05.2017

\begin{abstract}
The European Convention on Human Rights (ECHR) and the case-law of the European Court of Human Rights (ECtHR) influence the German legal system to a remarkable extent. In order to illustrate the impact of the Court's jurisprudence on German police law in particular, the present article will shed a light on the cases of Schwabe and M.G. v. Germany (no. 8080/08 and 8577/08) as well as Ostendorf v. Germany (no. 15598/08). These cases related to the question whether police custody-carried out for the mere purpose of preventing someone from committing a criminal offence - can be considered as compatible with the guarantees of the Convention, especially with the right to liberty and security as laid down in Article $5 \S 1$ ECHR. Since the Convention only allows deprivation of liberty in a strictly limited number of cases listed in Article 5 \& (2) ECHR, the Court had to undertake a detailed assessment of the eligible provisions and, thereby, give an answer to an ongoing controversy. Moreover, by refining its previous jurisprudence, the ECtHR did establish general human rights standards for purely preventive detention as governed by German police law. Therefore, the author will outline the Court's finding and, subsequently, examine the implementation of the requirements set out by the ECtHR into German law.
\end{abstract}

Keywords: case of Ostendorf v. Germany, case of Schwabe and M.G. v. Germany, European Convention on Human Rights, European Court of Human Rights, preventive police detention, right to liberty.

DOI: 10.17516/1997-1370-0099.

Research area: law.

\section{Introduction}

In 2011 and in 2013, the European Court of Human Rights (ECtHR) was called upon to decide whether and under which conditions preventive police detention (Präventivgewahrsam) can be considered as compatible with the guarantees of the European Convention on Human Rights
(ECHR). From a German point of view, these cases are highly interesting because the relevant actions had been taken under German law.

In the first case, Schwabe and M.G. v. Germany $^{1}$, the applicants had been arrested during the G8 summit held in Heiligendamm (located in the vicinity of Rostock) in June

(C) Siberian Federal University. All rights reserved

* Corresponding author E-mail address: clara.herz@uni-passau.de 
2007 because they were strongly suspected of preparing criminal acts, ${ }^{2}$ whereas the applicant in the second case, Ostendorf v. Germany ${ }^{3}$, had been taken into custody prior to a football match in April 2004 in order to prevent him from organising and taking part in a violent brawl between football hooligans. ${ }^{4}$

Both cases have in common that the detention was carried out for the mere purpose of preventing actions which - if carried out would have been punishable under German criminal law. ${ }^{5}$ Under these circumstances, the authorities were entitled to arrest the complainants on the basis of police law which is subject to the legislation of the German federal states (Bundesländer). For example, the Bavarian Police Tasks and Competencies Act (Bayerisches Polizeiaufgabengesetz) allows police custody "if this is indispensable in order to prevent the imminent commission or continuation of a criminal or regulatory offence of considerable importance to the general public" (section $17 \S 1$ no. 2; so-called Unterbindungsgewahrsam) ${ }^{6}$

Taking into account that these provisions govern detention for up to several days, ${ }^{7}$ then it can hardly be denied that there is a serious interference with the right to liberty and security as laid down in Article $5 \S 1$ (1) ECHR. However, deprivation of liberty can be justified under Article 5 § 1 (2) ECHR. This provision contains a limited number of cases in which the Convention exceptionally allows detention or arrest. Thus, by assessing the conventionality of the detention which had been contested by the applicants, the ECtHR had to determine, above all, whether preventive police detention falls within the scope of Article 5 § 1 (2) ECHR.

In this context, the ECtHR did not only refine its previous jurisprudence but the Court did also establish clear guidelines for preventive police detention. Therefore, as a first step, the present article aims to shed a light on the Court's finding. Subsequently, it is about to examine which consequences arise from the Court's finding with regard to police law in Germany.

\section{Preventive police custody in the light of the ECHR}

As already mentioned, the cases of Schwabe and M.G. and Ostendorf gave rise to a closer examination of Article $5 \S 1$ (2) ECHR. For this purpose, it is necessary to note that Article 5 $\S 1$ (2) ECHR contains an exhaustive list of permissible grounds for deprivation of liberty. ${ }^{8}$ This means that no custodial measure will be lawful unless it falls within the scope of one of the provisions listed in sub-paragraphs (a) to (f) of Article $5 \S 1$ (2) ECHR. ${ }^{9}$

\section{Justification under sub-paragraph (c)}

At first glance, it might seem fairly obvious that sub-paragraph (c) contains the relevant provision: the second limb of sub-paragraph (c) explicitly allows the detention of a person "when it is reasonably considered necessary to prevent his committing an offence".

However, in Schwabe and M.G. and in Ostendorf, the ECtHR held that this provision does not cover preventive police detention..$^{10}$ In order to understand the reasons for this finding, it is necessary to have a closer look at the entire wording of sub-paragraph (c).

This provision, as a whole, allows "the lawful arrest or detention of a person effected for the purpose of bringing him before the competent legal authority on reasonable suspicion of having committed an offence or when it is reasonably considered necessary to prevent his committing an offence or fleeing after having done so". Accordingly, every category of detention referred to in sub-paragraph (c) must be "effected for the purpose of bringing him [the person concerned] before the competent legal authority". 
Moreover, according to the case-law of the ECtHR, sub-paragraph (c) must be read in conjunction with Article 5 § 3 ECHR stating that "everyone arrested or detained in accordance with the provisions of paragraph 1 (c) of this Article shall be brought promptly before a judge $[\ldots]$ and shall be entitled to trial within a reasonable time". ${ }^{12}$

Therefore, the ECtHR concluded that subparagraph (c) only allows deprivation of liberty in connection with criminal proceedings. ${ }^{13}$ In other words: sub-paragraph (c) only governs pre-trial detention. ${ }^{14}$

But, in the case of Schwabe and M.G. and in the case of Ostendorf, the detention exclusively aimed at preventing, not at prosecuting offences. The applicants had been arrested for purely preventive purposes without being suspected of having already committed a criminal offence. Consequently, their custody was not aimed at bringing them before a judge in a criminal trial within the meaning of the Court's case-law. ${ }^{15}$ For these reasons, the ECtHR held that preventive police detention cannot be justified under subparagraph (c).

\section{Justification under sub-paragraph (b)}

However, preventive police detention as governed by German law may still be justified under sub-paragraph (b) of Article 5 § 1 (2) ECHR which allows the detention of a person "in order to secure the fulfilment of any obligation prescribed by law".

According to the ECtHR, detention under sub-paragraph (b) must "aim at or directly contribute to securing the fulfilment of the obligation and not be punitive in character"16. This provision concerns "cases where the law permits the detention of a person to compel him to fulfil a real and specific obligation already incumbent on him, and which he has until then failed to satisfy"17. Nevertheless, "the duty not to commit a criminal offence in the imminent future cannot be considered sufficiently concrete and specific [...], at least as long as no specific measures have been ordered which have not been complied with"18.

In Schwabe and M.G., the ECtHR could not find that the applicants had been under a specific and concrete obligation within the meaning of the Court's case-law. ${ }^{19}$ For this very reason, their detention could not be justified - neither under sub-paragraph (c), nor under sub-paragraph (b) and therefore amounted to a violation of Article $5 \S 1$ ECHR.

In Ostendorf, the situation was different, though. In this case, the ECtHR found that the applicant had been under the obligation to keep the peace by not committing a criminal offence as ordered by the police under section $32 \S 1$ no. 2 of the Hessen Public Security and Order Act (Hessisches Sicherheits- und Ordnungsgesetz). ${ }^{20}$ According to the Court, this obligation could be considered as sufficiently concrete and specific because the place and time of the imminent commission of the offence and its potential victims had been specified. ${ }^{21}$

Therefore, the Court's examination of sub-paragraph (b) had to go beyond the case of Schwabe and M.G.: The ECtHR was now called upon to decide whether the applicant in Ostendorf had failed to satisfy his obligation. ${ }^{22}$ Moreover, the ECtHR had to determine whether the applicant possibly had already fulfilled his obligation - in this case, the basis for detention under sub-paragraph (b) ceases to exist. ${ }^{23}$

For this purpose, the ECtHR established the following requirements: Purely preventive detention can only be justified under subparagraph (b) if, firstly, the person concerned "was made aware of the specific act which he or she was to refrain from committing" ${ }^{24}$. Secondly, the person concerned must have "taken clear and positive steps which indicate that he will 
not fulfil his obligation"25. Thirdly, in order to be released immediately, "a person could show prior to the moment the offence at issue was to take place that he or she was no longer willing to commit that offence - for instance by offering to leave and to stay away from the place of the planned offence and by supplying proof thereof" ${ }^{\prime 26}$. Fourthly, the detention must be proportionate which implies that a balance must be struck between the importance of securing the immediate fulfilment of the obligation not to commit a criminal offence and the importance of the right to liberty. ${ }^{27}$

\section{Implications of the Court's ruling}

The ECtHR has made clear that purely preventive detention can be justified, but only if strict requirements are met. ${ }^{28}$ With respect to an effective protection of human rights, the Court's finding should be highly welcomed. Moreover, the Court deserves approval when stating that only a narrow interpretation of the exceptions listed in Article $5 \S 1$ (2) ECHR may be consistent with the purpose of Article 5 ECHR which is to ensure that no one is subjected to arbitrary detention. ${ }^{29}$ Even the State's positive obligation to protect the public from impending criminal offences cannot justify a different assessment then. ${ }^{30}$

However, the finding of the Court is not entirely convincing. As outlined above, the second limb of sub-paragraph (c) ("when it is reasonably considered necessary to prevent his committing an offence") only governs detention in connection with criminal proceedings. This implies that this provision only is applicable in cases when someone has already committed a criminal offence and, in addition, is suspected of committing a criminal offence in the imminent future. ${ }^{31}$ In other words, this provision only covers pre-trial detention due to an imminent danger of re-offending (Untersuchungshaft wegen Wiederholungsgefahr). ${ }^{32}$
But, taking into account that the first alternative of sub-paragraph (c) already governs detention "on reasonable suspicion of having committed an offence", the second limb must appear as superfluous in addition to the first alternative. $^{33}$

On the other hand, the German legislator could, at least theoretically, declare early preparatory acts punishable under German criminal law so that the detention was not purely preventive anymore but rather effected for the purpose of prosecuting a criminal offence, thus "in connection with criminal proceedings" within the meaning of the Court's case-law. However, this approach would pretty much run counter to the aim of the Convention. ${ }^{34}$

Therefore, the German Government suggested a revision of the Court's wellestablished case-law. ${ }^{35}$ And although the Court explicitly rejected this proposal in the case of Ostendorf, ${ }^{36}$ judges Jäderblom and Lemmens indicated in their partly dissenting opinion that the Court's case-law could not, in fact, be considered as stringent as asserted by the majority. ${ }^{37}$

For this purpose, they referred to the Court's very first case, Lawless v. Ireland ${ }^{38}$, where the Court had held: Article $5 \S 3$ ECHR "plainly entails the obligation to bring everyone arrested or detained in any of the circumstances contemplated by the provisions of paragraph 1 (c) before a judge for the purpose of examining the question of deprivation of liberty or for the purpose of deciding on the merits" ${ }^{39} .40$ Thus, the Lawless case illustrates that Article 5 § 3 ECHR does not necessarily have to be interpreted as requiring a connection with criminal proceedings - in contrast to the later case-law which derogates from this early finding without any specific explanation. ${ }^{41}$

Nevertheless, even if the Court reversed its case-law in this particular respect, detention under sub-paragraph (c) would still require, 
just as sub-paragraph (b), the prevention of a concrete and specific offence. ${ }^{42}$ Moreover, even the dissenting judges held that, according to their reasoning, the detention in the case of Ostendorf would also have been justified - not under subparagraph (b), but under sub-paragraph (c). ${ }^{43}$

By indicating that "a number of the conditions that the majority lists under Article 5 $\S 1$ (b) [ECHR] are also relevant for a preventive detention under Article $5 \S 1$ (c) [ECHR] ${ }^{\prime 44}$, they reveal the main and genuine issue: In the end, it is not so much about to take a decision between sub-paragraphs (b) and (c) - it is rather about how to manage the risks ${ }^{45}$ involved with purely preventive detention.

Accordingly, the Court's finding that "Article $5 \S 1$ (c) [ECHR] [...] does not permit a policy of general prevention directed against an individual or a category of individuals who are perceived by the authorities, rightly or wrongly, as being dangerous or having propensity to unlawful acts" ${ }^{\text {"46 }}$ should also be considered as a guideline for the interpretation of sub-paragraph (b).

\section{Implementation of the Court's judgments into German law}

Beyond examining and deciding the particular cases of Schwabe and M.G. and Ostendorf, the ECtHR rather set up general requirements for preventive police detention. ${ }^{47}$ Therefore, it is necessary to have a closer look at the impact and the implementation of the Court's judgments into German law.

According to Article $59 \S 2$ of the German Constitution (Basic Law - Grundgesetz), the Convention formally has the status of an "ordinary" federal law within the German legal system. Taking into account that federal laws prevail over the laws of the German federal states (see Article 31 of the German Basic Law), this implies that the federal states' authorities have to interpret these subordinate provisions in accordance with the guarantees of the Convention.

Moreover, just as the German Federal Constitutional Court (Bundesverfassungsgericht) stated in its well-known case of Görgülü̈4, the guarantees of the ECHR and the entire case-law of the ECtHR even have to be considered, at least in principle, as guidelines for the interpretation of the German Basic Law itself. ${ }^{49}$ This means, for example, that the interpretation of the right to liberty as laid down in Article 2 § 2 (2) of the German Basic Law has to reflect the jurisprudence of the ECtHR relating to Article 5 of the Convention.

With regard to preventive police detention in particular, it can be noted that the relevant German provisions leave enough margin of appreciation in order to transpose the Court's requirements. Especially the principle of proportionality allows the implementation of the Court's case-law. ${ }^{50}$ For example, purely preventive detention will only be "indispensable" within the meaning of section $17 \S 1$ no. 2 of the Bavarian Police Tasks and Competencies Act if the person concerned has taken clear and positive steps which indicate that he or she will not fulfil the obligation imposed by the police.

So far, several administrative courts and even the German Federal Constitutional Court have acknowledged the assessment of the ECtHR by explicitly referring to the Ostendorf criteria. $^{51}$ However, the practical application of the Court's requirements still causes some problems $\mathrm{s}^{52}$ and it will probably take some more time until these uncertainties can be considered as removed.

\section{Concluding observations}

To sum up, in Schwabe and M.G. and in Ostendorf, the ECtHR determined that the mere purpose of preventing a criminal offence does 
not justify deprivation of liberty under subparagraph (c) but rather falls within the scope of sub-paragraph (b) of Article $5 \S 1$ (2) ECHR. At the same time, the Court made it clear that the ECHR sets very strict limits to purely preventive detention.

Especially with regard to the ongoing debate on how to face the threat of terrorist attacks and how to deal with persons who are perceived as being dangerous for this very reason (socalled Gefährder), the Court's human rights requirements for preventive police detention appear as even more important. Due to the Ostendorf criteria, the cases in which these persons may be taken into custody on the basis of German police law are now likely to be rather exceptional ones. On the other hand, if these cases go along with illegal immigration, deprivation of liberty can still be justified under sub-paragraph (f) ("arrest or detention of a person to prevent his effecting an unauthorised entry into the country") which is not affected by the Ostendorf criteria. $^{53}$

Nonetheless, preventive police detention will only be carried out in accordance with international human rights requirements if the relevant case-law of the ECtHR is taken into account. ${ }^{54}$ Thus, the Court's judgments in Schwabe and M.G. and in Ostendorf do not only illustrate the impact of the ECHR on the German legal system but they also contribute to the further development of human rights standards with regard to police law in Germany.

Appl. no. 8080/08 and 8577/08, judgment of 1 December 2011.

See ECtHR, Case of Schwabe and M.G. v. Germany, $\S 11 \mathrm{f}$.

Appl. no. 15598/08, judgment of 7 March 2013.

See ECtHR, Case of Ostendorf v. Germany, $\S \S 8 \mathrm{ff}$.

See ECtHR, Case of Schwabe and M.G. v. Germany, § 41; ECtHR, Case of Ostendorf v. Germany, $\S 37 \mathrm{ff}$.

${ }^{6}$ Moreover, see i.e. section $32 \S 1$ no. 2 of the Hessen Public Security and Order Act (Hessisches Gesetz über die öffentliche Sicherheit und Ordnung) as well as section $55 \S 1$ no. 2 of the Mecklenburg-West Pomerania Public Security and Order Act (Gesetz über die öffentliche Sicherheit und Ordnung in Mecklenburg-Vorpommern).

7 See i.e. section 20 no. 3 of the Bavarian Police Tasks and Competencies Act (up to two weeks); section $35 \S 1$ no. 4 of the Hessen Public Security and Order Act (up to six days); section 56 § (3) of the Mecklenburg-West Pomerania Public Security and Order Act (up to ten days).

8 ECtHR, Case of Schwabe and M.G. v. Germany, § 69; ECtHR, Case of Ostendorf v. Germany, § 65.

9 ECtHR, Case of Schwabe and M.G. v. Germany, § 69; ECtHR, Case of Ostendorf v. Germany, § 65.

10 ECtHR, Case of Schwabe and M.G. v. Germany, § 80; ECtHR, Case of Ostendorf v. Germany, § 89.

11 See ECtHR, Case of Schwabe and M.G. v. Germany, § 71; ECtHR, Case of Ostendorf v. Germany, § 67.

12 ECtHR, Case of Schwabe and M.G. v. Germany, § 72; ECtHR, Case of Ostendorf v. Germany, § 68.

13 ECtHR, Case of Schwabe and M.G. v. Germany, § 72; ECtHR, Case of Ostendorf v. Germany, § 68; for a critical assessment see Heidebach, NVwZ 2014, p. 554 (556 f.).

14 ECtHR, Case of Schwabe and M.G. v. Germany, § 79; ECtHR, Case of Ostendorf v. Germany, §§ 68, 82.

15 ECtHR, Case of Schwabe and M.G. v. Germany, § 79; ECtHR, Case of Ostendorf v. Germany, §§ 68, 82.

16 ECtHR, Case of Schwabe and M.G. v. Germany, § 73; ECtHR, Case of Ostendorf v. Germany, §§ 71, 97.

17 ECtHR, Case of Schwabe and M.G. v. Germany, § 73; ECtHR, Case of Ostendorf v. Germany, § 69.

18 ECtHR, Case of Schwabe and M.G. v. Germany, § 82; ECtHR, Case of Ostendorf v. Germany, § 70; moreover, see Esser, NJW 2016, p. 604 (605).

19 ECtHR, Case of Schwabe and M.G. v. Germany, $\S 80 \mathrm{ff}$.

20 ECtHR, Case of Ostendorf v. Germany, $\S \S 91$ f.; in contrast, see the separate opinion of judges Jäderblom and Lemmens holding that " the obligation not to commit criminal acts or regulatory offences (see section $32 \S 1$ no. 2 of the Hessen Public Security and Order Act) is in our opinion too general for the purpose of Article $5 \S 1$ (b) of the Convention" (annex to ECtHR, Case of Ostendorf v. Germany, § 3).

21 ECtHR, Case of Ostendorf v. Germany, § 93.

22 ECtHR, Case of Ostendorf v. Germany, § 94.

23 ECtHR, Case of Ostendorf v. Germany, $\S \S 72,99$.

24 ECtHR, Case of Ostendorf v. Germany, § 94.

25 ECtHR, Case of Ostendorf v. Germany, § 94.

26 ECtHR, Case of Ostendorf v. Germany, § 100.

27 See ECtHR, Case of Ostendorf v. Germany, $\S$ 73, 101.

28 See Karpenstein/Mayer/Elberling, Art. 5 ECHR, par. 41a; HK-EMRK/Meyer-Ladewig/Harrendorf/König, Art. 5 ECHR, par. 37; Renzikowski/Schmidt-De Caluwe, JZ 2013, p. 289 (292).

29 See ECtHR, Case of Ostendorf v. Germany, $\S$ 65, 74, 94; Heidebach, NVwZ 2014, p. 554 (556); moreover, see Ashworth/ Zedner, p. 64. 
30 See ECtHR, Case of Ostendorf v. Germany, § 87; Renzikowski/Schmidt-De Caluwe, JZ 2013, p. 289 (293); moreover, see Ashworth/Zedner, p. 61 f.; in contrast, see the Government's submissions in ECtHR, Case of Schwabe and M.G. v. Germany, § 62; ECtHR, Case of Ostendorf v. Germany, § 52.

31 See Karpenstein/Mayer/Elberling, Art. 5 ECHR, par. 56; Löwe-Rosenberg/Esser, Art. 5 ECHR, par. 133; Heidebach, NVwZ 2014, p. 554 (556).

32 See Karpenstein/Mayer/Elberling, Art. 5 ECHR, par. 56; Renzikowski/Schmidt-De Caluwe, JZ 2013, p. 289 (291); different assessment by SK-StPO/Paeffgen, Art. 5 ECHR, par. 33 (prior to the Ostendorf judgment).

33 See the Government's submissions in ECtHR, Case of Schwabe and M.G. v. Germany, § 61; ECtHR, Case of Ostendorf v. Germany, § 51; Karpenstein/Mayer/Elberling, Art. 5 ECHR, par. 49, 56; Heidebach, NVwZ 2014, p. 554 (556); Esser, NJW 2016, p. 604 (605).

34 See the Government's submission in ECtHR, Case of Ostendorf v. Germany, § 55; moreover, see Hoffmann, NVwZ 2015, p. 720 (723).

35 See the Government's submissions in ECtHR, Case of Schwabe and M.G. v. Germany, § 61; ECtHR, Case of Ostendorf v. Germany, § 51 .

36 See ECtHR, Case of Ostendorf v. Germany, $\S 84 \mathrm{ff}$.

37 Annex to ECtHR, Case of Ostendorf v. Germany, $\$ 4$.

Appl. no. 332/57, judgment of 1 July 1961.

ECtHR, Case of Lawless v. Ireland (No. 3), examination of the law, 114 (p. 24).

Annex to ECtHR, Case of Ostendorf v. Germany, $\S 4$.

Annex to ECtHR, Case of Ostendorf v. Germany, $\S 4$

See ECtHR, Case of Schwabe and M.G. v. Germany, § 70; ECtHR, Case of Ostendorf v. Germany, § 66.

Annex to ECtHR, Case of Ostendorf v. Germany, § 1 .

Annex to ECtHR, Case of Ostendorf v. Germany, § 5 .

See i.e. ECtHR, Case of Shimovolos v. Russia, § 56; Ashworth/Zedner, p. 62.

46 See ECtHR, Case of Ostendorf v. Germany, § 66; ECtHR, Case of Shimovolos v. Russia, § 54.

47 See i.e. German Federal Constitutional Court, Case of Görgülü, NJW 2004, p. 3407 (3409); Karpenstein/Mayer/Breuer, Art. 46 ECHR, par. $31 \mathrm{ff}$.

48 German Federal Constitutional Court, Case no. BvR 1481/04; decision of 14 October 2004.

49 See German Federal Constitutional Court, Case of Görgülü, NJW 2004, p. 3407 (3408).

50 See Scheidler, NVwZ 2012, p. 1083 (1085); Waechter, NVwZ 2014, p. 995 (997).

51 See i.e. German Federal Constitutional Court, NVwZ 2016, p. 1079 (1080); Higher Administrative Court (Oberverwaltungsgericht) Lüneburg, NVwZ-RR 2014, p. 552 (556); Higher Administrative Court Bremen, BeckRS 2015, 48609 (par. 43 ff.).

52 See Higher Administrative Court Lüneburg, NVwZ-RR 2014, p. 552 (557); Heidebach, NVwZ 2014, p. 554 (558); Waechter, NVwZ 2014, p. 995 (996); Hoffmann, NVwZ 2015, p. 720 (722).

53 See ECtHR, Case of A. and others v. UK, § 164; Karpenstein/Mayer/Elberling, Art. 5 ECHR, par. 81; Waechter, NVwZ 2014, p. 995; in detail, see Walther, ZIS 2007, p. 464 (469 ff.).

54 See Renzikowski/Schmidt-De Caluwe, JZ 2013, p. 289 (293); Heidebach, NVwZ 2014, p. 554 (558).

\section{References}

Ashworth, A., Zedner L. (2015). Preventive justice. Oxford: Oxford University Press.

Case of Lawless v. Ireland (No. 3), judgment of 1 July 1961. European Court of Human Rights. Appl. no. 332/57.

Case of A. and others v. UK, judgment of 19 February 2009. European Court of Human Rights. Appl. no. 3455/05.

Case of Schwabe and M.G. v. Germany, judgment of 1 December 2011. European Court of Human Rights. Appl. no. 8080/08 and 8577/08. Neue Zeitschrift für Verwaltungsrecht (NVwZ) 2012, 1089-1095.

Case of Ostendorf v. Germany, judgment of 7 March 2013. European Court of Human Rights. Appl. no. 15598/08. Neue Zeitschrift für Verwaltungsrecht (NVwZ) 2014, 43-49.

Case of Shimovolos v. Russia, judgment of 21 June 2011. European Court of Human Rights. Appl. no. $30194 / 09$.

Case no. 2 BvR 1481/04, Case of Görgülü, decision of 14 October 2004. German Federal Constitutional Court. Neue Juristische Wochenschrift (NJW) 2004, 3407-3412.

Cases no. 2 BvR 1833/12 and 2 BvR 1945/12, decision of 18 April 2016. German Federal Constitutional Court. Neue Zeitschrift für Verwaltungsrecht (NVwZ) 2016, 1079-1081. 
Case no. 1 A 251/12, judgment of 9 June 2015. Higher Administrative Court Bremen. BeckRechtsprechung (BeckRS) 2015, 48609.

Case no. 11 LC 228/12, judgment of 24 February 2014. Higher Administrative Court Lüneburg. Neue Zeitschrift für Verwaltungsrecht - Rechtsprechungs-Report (NVwZ-RR) 2014, 552-557.

Esser, R. (2016). Die Judikatur des EGMR im Strudel der Anhörungsrüge. Neue Juristische Wochenschrift (NJW), 604-609.

Heidebach, M. (2014). Der polizeiliche Präventivgewahrsam auf konventionsrechtlichem Prüfstand. Neue Zeitschrift für Verwaltungsrecht (NVwZ), 554-558.

HK-EMRK: Meyer-Ladewig, J., Nettesheim, M., von Raumer, S. (eds.). (2017). Handkommentar zur Europäischen Menschenrechtskonvention. 4th edition. Baden-Baden: Nomos.

Hoffmann, M. (2015). Konventionskonformität des Präventivgewahrsams. Neue Zeitschrift für Verwaltungsrecht (NVwZ), 720-723.

Karpenstein, U., Mayer, F. (eds.). (2015). Kommentar zur Europäischen Menschenrechtskonvention. 2nd edition. Munich: C.H. Beck.

Löwe-Rosenberg: Erb, V., Esser, R., Franke, U., Graalmann-Scheerer, K., Hilger, H., Ignor, A. (eds.). (2012). Löwe-Rosenberg, Großkommentar zur Strafprozessordnung und zum Gerichtsverfassungsgesetz. Volume 11: EMRK/IPBPR. 26th edition. Berlin, Boston: De Gruyter.

Renzikowski, J., Schmidt-De Caluwe, R. (2013). Menschenrechtliche Grenzen des polizeilichen Unterbindungsgewahrsams. Juristenzeitung (JZ), 289-297.

Scheidler, A. (2012). Beschränkung der Ingewahrsamnahme von Personen zur Gefahrenabwehr durch den EGMR. Neue Zeitschrift für Verwaltungsrecht (NVwZ), 1083-1085.

SK-StPO: Wolter, J. (ed.). (2012). Systematischer Kommentar zur Strafprozessordnung. Volume 10: EMRK. 4th edition. Cologne: Carl Heymanns Verlag.

Waechter, K. (2014). Unterbindungsgewahrsam mit EMRK unvereinbar. Neue Zeitschrift für Verwaltungsrecht (NVwZ), 995-998.

Walther, S. (2007). Präventivhaft für terrorismusverdächtige „Gefährder“: eine Option für Deutschland? Zeitschrift für Internationale Strafrechtsdogmatik (ZIS), 464-475.

\title{
Влияние Европейской конвенции \\ о защите прав человека (ЕКЗПЧ) \\ на превентивное задержание полицией, регулируемое законодательством Германии
}

\author{
К. Херц \\ Университет Пассау \\ Германия
}

Европейская конвенция о защите прав человека (ЕКЗПЧ) и судебная практика Европейского суда по правам человека (ЕСПЧ) оказывают значительное влияние на законодательную систему Германии. Для того чтобы наглядно продемонстрировать влияние судебной прак- 
тики на полицейское законодательство Германии, в данной статье рассматриваются дела Швабе и М.Г. против Германии (№ 8080/08 и 8577/08), а также Остендорф против Германии (№ 15598/08). Данные дела связаны с вопросом о том, считается ли содержание под стражей в полиции, осуществленное с простой целью предотвращуения совершения кем-либо уголовного преступления, соответствующчим гарантиям Конвенциии, особенно правам на свободу и личную неприкосновенность, закрепленным в статье 5 \& ЕКЗПЧ. Поскольку Конвенции допускает лишение свободы только в строго ограниченном числе случаев, перечисленных в статье $5 \S$ 1(2)ЕКЗПЧ, суд должен был провести детальную оценку приемлемых положений и тем самым разрешить текущчие разногласия. Более того, путем оптимизации своей предыдущей судебной практики ЕСПЧ установил общче стандарты прав человека, регулируемые полицейским законодательством Германии, для исключительно превентивного задержания. Автор представит выводы суда и последовательно рассмотрит применение требований, установленных ЕСПЧ в немецком законодательстве.

Ключевые слова: дело Остендорф против Германии, дело Швабе и М.Г. против Германии, Европейская конвенция о защчите прав человека, Европейский суд по правам человека, превентивное задержание полицией, право на свободу.

Научная специальность: 12.00.00 - юридические науки. 